慶應義塾大学学術情報リポジトリ

Keio Associated Repository of Academic resouces

\begin{tabular}{|c|c|}
\hline Title & The carbohydrate structure of a mucilage from the roots of hibiscus moscheutos L. \\
\hline \multicolumn{2}{|l|}{ Sub Title } \\
\hline Author & $\begin{array}{l}\text { 友田，正司(Tomoda, Masashi) } \\
\text { 嶋田，和代(Shimada, Kazuyo) } \\
\text { 清水，訓子(Shimizu, Noriko) } \\
\text { 金成，美枝子(Kanari, Mieko) } \\
\text { 金子，恵美子(Kaneko, Emiko) }\end{array}$ \\
\hline Publisher & 共立薬科大学 \\
\hline Publication year & 1986 \\
\hline Jtitle & $\begin{array}{l}\text { 共立薬科大学研究年報 (The annual report of the Kyoritsu College of } \\
\text { Pharmacy). No.31 (1986. ), p.37- } 38\end{array}$ \\
\hline \multicolumn{2}{|l|}{ JaLC DOI } \\
\hline \multicolumn{2}{|l|}{ Abstract } \\
\hline Notes & 抄録 \\
\hline Genre & Technical Report \\
\hline URL & $\begin{array}{l}\text { https://koara.lib.keio.ac.jp/xoonips/modules/xoonips/detail.php?koara_id=AN00062898-0000003 } \\
\text { 1-0037 }\end{array}$ \\
\hline
\end{tabular}

慶應義塾大学学術情報リポジトリ(KOARA)に掲載されているコンテンツの著作権は、それぞれの著作者、学会または出版社/発行者に帰属し、その権利は著作権法によって 保護されています。引用にあたっては、著作権法を遵守してご利用ください。

The copyrights of content available on the KeiO Associated Repository of Academic resources (KOARA) belong to the respective authors, academic societies, or publishers/issuers, and these rights are protected by the Japanese Copyright Act. When quoting the content, please follow the Japanese copyright act. 
No. 31 (1986)

\title{
The Carbohydrate Structure of a Mucilage from the Roots of Hibiscus moscheutos L.*
}

\author{
Masashi Tomoda, Kazuyo Shimada, Noriko Shimizu, Mieko Kanari, \\ and Emiko KANEKo
}

友田正司, 嶋田和代, 清水訓子, 金成美枝子, 金子恵美子

Many mucilages are found in various plants in the Malvaceae family. The roots and leaves of some plants have been used as emollients, demulcents, and as cough medicines. Further, some mucilages have been used as sizes and as a plasma expander. In the previous papers of this series, the isolation and structural features of representative mucilages from the roots and leaves of Althaea officinalis L., the roots of Abelmoschus manihot Medicus, the roots of Abelmoschus glutinotextilus KAGAwA, the immature fruits and roots of Abelmoschus esculentus Moench, and the roots and leaves of Althaea rosea Cavailles have been reported from our laboratory.

These studies are concerned with the mucilages from plants in the Althaea and Abelmoschus genera, but no structural study on the mucilages from plants in the Hibiscus genus has been reported thus far. We now report the isolation and structural investigation of a representative mucilage from the roots of Hibiscus moscheutos L.

The mucilage was isolated from the fresh roots by sequential cold-water extraction, ethanol precipitation, selective precipitation with cetyltrimethylammonium bromide, ethanol precipitation, gel chromatography with Sephadex G-25, and lyophilization.

The mucilage was homogeneous as determined by ultracentrifugal analysis, and gave a single spot on zone electrophoresis with a cellulose acetate membrane and with glassfiber paper. In addition, it gave a clear band on polyacrylamide gel disk electrophoresis. Both the periodate-Schiff reagent and the coomassie blue reagent revealed the band in the same position. Further, it gave a single peak on gel chromatography with Sephacryl S-400. The mucilage had $[\alpha]_{\mathrm{D}}^{25}+48.5^{\circ}$, and its aqueous solution gave the high intrinsic viscosity value of 32.2 at $30^{\circ}$. Gel chromatography with standard dextrans gave a value of $1,900,000$ for the molecular weight. The name "Hibiscus-mucilage Mo" is proposed for this substance.

As component sugars of the mucilage, rhamnose, galacturonic acid, and glucuronic acid were identified. The carboxyl groups of hexuronic acids in the mucilage were reduced to give the corresponding neutral suger residues. The carboxyl-reduced derivative thus obtained contained component sugars in almost equimolar proportions. Quantitative determination showed that the mucilage contained $22.5 \%$ rhamnose, $24.5 \%$ galacturonic

* 本報告は Carbohydr. Res., 151, 29-35（1986）に発表. 
No. 31 (1986)

acid, and 24.5\% glucuronic acid. The IR spectrum showed absorption bands at 1250 and $1725 \mathrm{~cm}^{-1}$, suggesting the presence of ester linkages. The acid hydrolyzate gave a single peak with a retention time equal to that of acetic acid by GLC. The acetyl content of the mucilage was determined to be $8.0 \%$. The mucilage contained $2.7 \%$ nitrogen. The amino acid composition after hydrolysis with $6 \mathrm{M}$ hydrochloric acid is listed. No compound other than carbohydrates and amino acids was detected in the hydrolyzate.

The carboxyl-reduced mucilage was methylated by the Hakomori method. The methylated product was hydrolyzed, and the products were converted into the partially methylated alditol acetates. GLC-MS revealed derivatives of 3,4-di-O-methylrhamnose, 2,3,4,6tetra-O-methylglucose, and 2,6-di-O-methylgalactose as the products in a molar ratio of $1.0: 0.9: 1.1$.

The mucilage was partially hydrolyzed with dilute sulfuric acid, and then made neutral and treated with Dowex 50W $\left(\mathrm{H}^{+}\right)$. The eluate with water was applied to a column of DEAE-Sephadex A-25 (formate form). In addition to small amounts of component monosaccharides, five oligosaccharides $(\mathbf{1}-\mathbf{5})$ were obtained by stepwise elution with dilute formic acid. Based on the results of component-sugar analysis and a comparison of their chromatographic properties, their ${ }^{1} \mathrm{H}-\mathrm{NMR}$ spectra, and their specific rotations with those of authentic samples, $\mathbf{1 - 5}$ were identified.

Based on the accumulated evidence described here, it may be concluded that the polysaccharide moiety of the mucilage is built up from repeating units of the following structure.

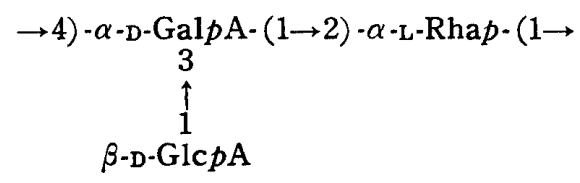

